\title{
Histone H2A-Bbd Type 2/3
}

National Cancer Institute

\section{Source}

National Cancer Institute. Histone H2A-Bbd Type 2/3. NCI Thesaurus. Code C154656.

Histone H2A-Bbd type 2/3 (115 aa, $13 \mathrm{kDa}$ ) is encoded by the human H2AB2 and $\mathrm{H} 2 \mathrm{AB} 3$ genes. This protein plays a role in the promotion of gene expression. 